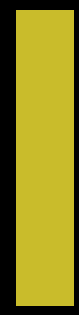

PANDEMIC ROUNDTABLE; THE LABOR MOVEMENT AS AN EDUCATIONAL MOVEMENT; GENDER, RACE, AND MIGRANT LABOR IN THE "DOMESTIC FRONTIER" OF THE PANAMA CANAL ZONE

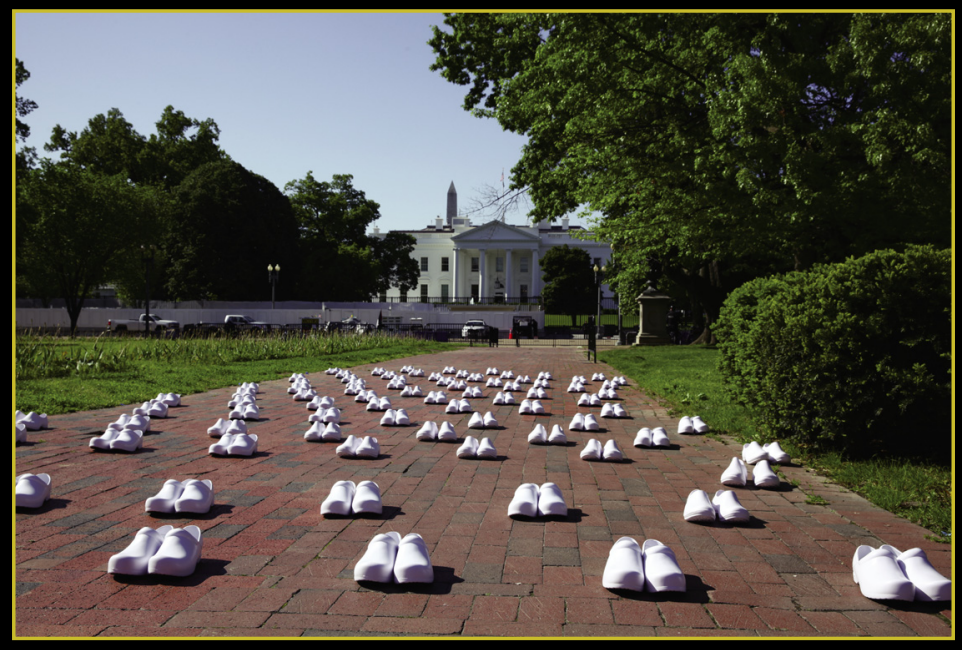

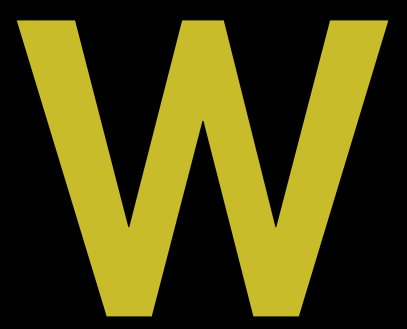
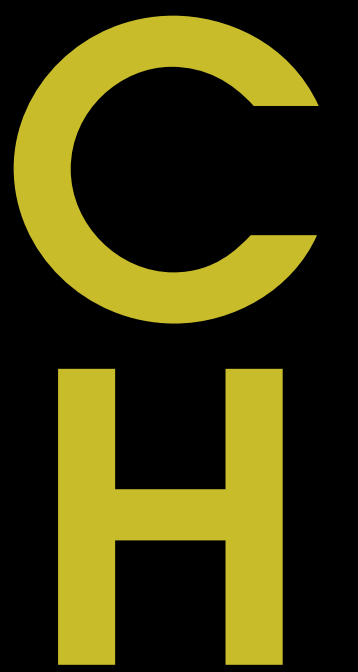

Number 99

Spring 2021
CAMbridge UNIVERSITY PRESS 


\section{INTERNATIONAL LABOR AND WORKING-CLASS HISTORY}

\section{SENIOR EDITORS}

Franco Barchiesi

Ohio State University

Kate Brown

Massachusetts Institute

of Technology, Cambridge

Marjoleine Kars

University of Maryland

Baltimore Count (UMBC)

\section{ASSOCIATE EDITOR}

Marcel van der Linden

International Institute of

Social History, Amsterdam

\section{REVIEW EDITOR}

Thai Jones

Columbia University

MANAGING EDITOR

Gabriel Antonio Solis

Columbia University
EDITORIAL BOARD

Aaron Benanav

Humboldt University of Berlin

Mae Ngai

Columbia University

Carolyn Brown

Rutgers University

Jacob Eyferth

University of Chicago

Lori Flores

Stony Brook University

Jennifer Klein

Yale University

Talitha LeFlouria

University of Virginia
Mary Nolan

New York University

Prasannan Parthasarathi Boston College

Amy Stanley Northwestern University

Barbara Weinstein New York University

Peter Winn

Tufts University

Xiaodan Zhang

York College, CUNY

\section{EDITORS EMERITUS}

Ira Katznelson

Columbia University

International Labor and Working-Class History (ISSN 0147-5479) is published twice yearly, in the spring and the fall, by Cambridge University Press for the editors of $I L W C H$. Annual subscription rates for Numbers 99 and 100 , Spring and Fall (2021): Institutional subscription rates, print and online: US \$259 in the USA, Canada, and Mexico; UK $£ 161$ + VAT elsewhere. Institutional subscription rate, online only: US \$207 in the USA, Canada, and Mexico; UK $£ 127$ + VAT elsewhere. Institutional subscription rate, print only: US \$238 in the USA, Canada, and Mexico; UK £145 + VAT elsewhere. Individuals subscription rate, print and online: US \$74 in the USA, Canada, and Mexico; UK $£ 42+$ VAT elsewhere. Individuals subscription rate, print only: US \$66 in the USA, Canada, and Mexico; UK £31 + VAT elsewhere. Prices include surface postage. International Labor and Working-Class History is indexed in ABC-CLIO; Alternative Press Index; American Bibliography of Slavic and East European Studies; America: History and Life; Arts and Humanities Citation Index; Current Contents: Arts and Humanities; Historical Abstracts; Left Index; Middle East: Abstracts and Index; and Sociological Abstracts.

Editorial Office: Manuscripts, editorial correspondence, and books for review should be addressed to Managing Editor, International Labor and Working-Class History, Columbia University, 1180 Amsterdam Avenue, Box \#60, MC: 2569, New York, NY, 10027 USA or via email: ILWCH@ columbia.edu

Publishing, Subscription, and Advertising Offices: Cambridge University Press, One Liberty Plaza, $20^{\text {th }}$ Floor, New York, NY 10006. Tel: 1-800-872-7423. Fax: 1-212-337-5959; or Cambridge University Press, University Printing House, Shaftesbury Road, Cambridge CB2 8BS, UK. Tel: +44(0) 223325806. Fax: +44(0)223 315052. E-mail: journals_marketing@cambridge.org. See also http://www.cambridge.org.

Copyright (C) 2021 International Labor and Working-Class History, Inc. All rights reserved. No part of this publication may be reproduced, in any form or by any means, electronic, photocopying or otherwise, without permission in writing from Cambridge University Press. Photocopying information for users in the USA: The Item-Fee Code for this publication (ISSN 0147-5479/15 \$15.00) indicates that copying for internal or personal use beyond that permitted by Sec. 107 or 108 of the US Copyright Law is authorized for duly registered with the Copyright Clearance Center (CCC) Transaction Reporting Service, provided that the appropriate remittance of $\$ 15.00$ per article is paid directly to: CCC, 222 Rosewood Drive, Danvers, MA 01923. Specific written permission must be obtained for all other copying.

The Board of Consulting Editors may be found immediately following the contents. See the back inside cover of the journal for information concerning submissions to the journal.

Cover Image: Photo taken by Rick Reinhard on May 7, 2020 in Lafayette Park in front of the White House-part of an event the National Nurses United (NNU) organized to remember 88 nurses who lost their lives to COVID 19, due to the lack of sufficient and appropriate PPE. 


\title{
PANDEMIC ROUNDTABLE
}

And the Virus Rages on: "Contingent" and "Essential" Workers in the Time of COVID-19

Annelise Orleck

The Humanization of Nature and Half-Earth Socialism

Drew Pendergrass and Troy Vettese

Notes on Essential Labor

Verónica Gago and Translated by Liz Mason-Deese

"Inoculations: The Social Politics of Time, Labor, and Public Good in COVID-America"

Jennifer Klein

Foxconn, Ciudad Juárez, and the Trials of Solidarity

Gabriel Solis

The Etymology of Despair in the Americas

Ernesto Semán

Service Work in the Pandemic Economy

Aaron Benanav

\begin{abstract}
ARTICLES
The Labor Movement As an Educational Movement: A Conceptual History of Sivistys Within the Finnish Workers' Educational Association 1920s-1960s Elina Hakoniemi
\end{abstract}

Gender, Race, and Migrant Labor in the "Domestic Frontier" of the Panama Canal Zone Joan Flores-Villalobos

A Failed Experiment: Okinawan Indents and the Postwar Torres Strait Pearlshelling Industry, 1958-1963

Anna Shnukal

British Workers and Ottoman Modernity in Nineteenth-Century Istanbul

Akın Sefer 
Sartre as prosecutor of occupational murder: notes from a People's Tribunal in a French mine (1970)

Pascal Marichalar, Gerald Markowitz and David Rosner 


\section{BOARD OF CONSULTING EDITORS}

Risto Alapuro

University of Helsinki

Kathryn Amdur

Emory University

Eric Arnesen

The George Washington University

Touraj Atabaki

International Institute of Social History,

Amsterdam

Joel Beinin

Stanford University

Gerd Callesen

Arbejderbevaegelsens Bibliotek og Arkiv,

Copenhagen

Jane Caplan

St. Antony's College, Oxford

Frederick Cooper

New York University

Jefferson Cowie

Cornell University

Patrizia Dogliani

University of Bologna

Geoff Eley

University of Michigan

Elizabeth Faue

Wayne State University

Paulo Fontes

Universidade Federal do Rio de Janeiro

Joshua Freeman

CUNY Graduate Center

John French

Duke University

Patrick Fridenson

Ecole des Hautes Etudes en Sciences

Sociales

Wendy Z. Goldman

Carnegie Mellon University

Andrew Gordon

Harvard University

Linda Gordon

New York University
Rick Halpern

University of Toronto

Victoria Hattam

New School for Social Research

William P. Jones

University of Wisconsin,

Madison

Don Kalb

Central European University

Linda Kerber

University of Iowa (Emeritus)

Neville Kirk

Manchester Metropolitan University

Deborah Levenson-Estrada

Boston College

Bruce Levine

University of Illinois,

Champaign-Urbana

Earl Lewis

University of Michigan

Nelson Lichtenstein

University California, Santa

Barbara

Mary Jo Maynes

University of Minnesota

Gwendolyn Mink

Independent Scholar

Mary Nash

University of Barcelona

Silke Neunsinger

Labour Movement Archives

and Library, Sweden

Elizabeth Perry

Harvard University

Anson Rabinbach

Princeton University

Pamela Radcliff

University of California, San Diego

Dilip Simeon

Aman Trust 